NBER WORKING PAPER SERIES

\title{
EXCHANGE RATES AND ADJUSTMENT: PERSPECTIVES FROM THE NEW OPEN ECONOMY MACROECONOMICS
}

\author{
Maurice Obstfeld \\ Working Paper 9118 \\ http://www.nber.org/papers/w9118 \\ NATIONAL BUREAU OF ECONOMIC RESEARCH \\ 1050 Massachusetts Avenue \\ Cambridge, MA 02138 \\ August 2002
}

This paper was prepared for the Bank of Japan's $10^{\text {th }}$ international research conference, Tokyo, Japan, July 1-2, 2002. Julian di Giovanni provided expert research assistance. I am grateful for a discussion with Giancarlo Corsetti. All errors and opinions are mine. Support from the National Science Foundation of the United States, through a grant to the National Bureau of Economic Research, is acknowledged with thanks. The views expressed herein are those of the author and not necessarily those of the National Bureau of Economic Research.

(C) 2002 by Maurice Obstfeld. All rights reserved. Short sections of text, not to exceed two paragraphs, may be quoted without explicit permission provided that full credit, including $\mathbb{C}$ notice, is given to the source. 
Exchange Rates and Adjustment: Perspectives from the New Open Economy Macroeconomics Maurice Obstfeld

NBER Working Paper No. 9118

August 2002

JEL No. F31, F32, F41

\begin{abstract}
The New Open Economy Macroeconomics has allowed economists to tackle classical problems with new tools, while also generating new ideas and questions. In their attempts to make the new models capture empirical regularities, researchers have entertained a variety of assumptions about the international pricing of goods, notably, models of pricing to market and destination-currency pricing of exports. Some of the resulting models imply that exchange-rate changes lack international expenditure-switching effects, and they thus appear to call for a radical rethinking of the role of exchange rates in international adjustment. This paper argues that the recent resurgence of exchange-rate pessimism stems from oversimplified modeling strategies rather than from evidence. Like earlier episodes starting with the extreme "elasticity pessimism" of the early postwar era, it is based on a misinterpretation of the empirical record.
\end{abstract}

Maurice Obstfeld

Department of Economics

University of California, Berkeley

549 Evans Hall \#3880

Berkeley, CA 94720-3880

and NBER

obstfeld@econ.berkeley.edu 


\section{Introduction}

Recent research on open economy macroeconomics has produced a synthesis of dynamic intertemporal approaches with older sticky-price models of macroeconomic fluctuations. This synthesis, which has become known as the New Open Economy Macroeconomics, has allowed economists to tackle classical problems with new tools, while also generating new ideas and questions. The presence of a foundation in microeconomic optimization allows a rigorous welfare analysis of policies and regimes. The approach also invites a rich analysis of alternative product, labor, and asset-market structures.

In their attempts to make these models capture empirical regularities more accurately, researchers have entertained a variety of assumptions regarding the behavior of international prices. Some of these models appear to call for a radical rethinking of conventional views on the role of exchange rates in international adjustment. ${ }^{1}$ It is a good illustration of the power of the new approach, but also a matter of vast consequence for policy analysis, to reconsider the stabilization benefits of exchange rate flexibility. Pessimism over the gross benefits of flexible exchange rates is a perennial feature of the intellectual landscape, and the newest bout is based on the observation of extremely low and slow pass-through of exchange rate changes to consumer prices. I argue below that the recent resurgence of exchange-rate pessimism stems from oversimplified modeling strategies rather than from evidence. Like earlier episodes starting with the extreme "elasticity pessimism" of the early postwar era, it is based on a misinterpretation of the empirical record. In reality, the case that exchange rates are an aid in international adjustment remains strong - at least for now.

\section{Five Varieties of Exchange Rate Pessimism}

Do exchange rate changes promote international adjustment? The question is an old one; so old, indeed, that its meaning has evolved substantially over the years. When the Bretton Woods institutions began operating in the late 1940 s , the term "international adjustment" was widely understood in terms of restoring equilibrium in the balance of payments. Exchange depreciation, say, would reduce a payments deficit if had effects on international relative

\footnotetext{
${ }^{1}$ For an excellent survey taking a more formally analytic approach than this one, see Engel (2002).
} 
prices leading to sufficiently higher export and lower import levels. Nowadays, one might ask instead whether exchange-rate variation is an essential implication of welfare-maximizing policy feedback rules. But the basic implication for the currency regime of a negative answer has not changed. If exchange rate changes play no beneficial role - by cushioning the effects of shocks on international payments or aggregate activity - then a credible fixed exchange rate regime such as a currency union is preferred to one entailing variable exchange rates. In light of the persistence of debate over the optimal currency regime, it is no surprise that the potential inefficacy of exchange rate changes has been a constant theme in the literature. That theme, however, has had many variations that are sometimes overlapping but sometimes mutually inconsistent. A review of these many variations is useful, however, as it provides a capsule history of thought that serves to put current debates into perspective. ${ }^{2}$

\subsection{Variation 1: Classic Elasticity Pessimism}

Starting with studies by Tinbergen in the mid-1930s (see Tinbergen 1937), empirical researchers of the pre- and early post-World War II era formed the view that price elasticities in export and import demand were quite lowtoo low, for example, to satisfy the classic Marshall-Lerner condition under which a currency depreciation will improve the trade balance. Thus Metzler (1948, p. 232) concluded that

Considering the low price elasticities which have been found in most empirical studies of demand, it seems probable that depreciation, in the short run, cannot improve a country's trade balance unless the inelastic demand for imports is matched by a corresponding inelastic supply of exports. Even in this case the

\footnotetext{
${ }^{2}$ Below I restrict the discussion, perhaps somewhat artificially, to pessimistic assessments of the direct (and partial) effects of exchange rate changes on relative international prices and demands, holding income and wealth levels constant. Thus, I am ignoring the fact that exchange rate changes can have collateral contractionary effects, for example, through balance sheets, that could nullify or reverse any potential expansionary effect due to expenditure switching among countries. In this paper, the question is whether the partial expenditure-switching effects themselves are substantially positive over a relevant horizon.
} 
elasticity of the trade balance will probably be small, and a substantial movement of exchange rates may therefore be required to eliminate rather modest deficits. In other words, over comparatively short periods of time, movements of exchange rates are not an efficient means of allocating resources between foreign and domestic use.

Metzler went on to argue that these conclusions rationalized the Bretton Woods emphasis on exchange stability as well as the use of direct import controls, though he also suggested that trade elasticities are higher in the long run, justifying currency realignment (notwithstanding short-run negative effects on the trade balance) in situations of fundamental disequilibrium.

A famous paper by Orcutt (1950), written at the IMF's research department (see Blejer et al. 1995), showed how aggregation bias, simultaneity bias, lags, and other factors, could lead a naive econometrician to find low trade elasticities even when elasticities were quite high. See also Machlup (1950), who apparently coined the phrase "elasticity pessimism." Subsequent research, including work on disaggregated data, suggests that trade elasticities really are higher over an annual horizon than the earliest statistical studies suggested. For reasons that I will take up in a later section, the elasticities are no doubt significantly higher today than the were at the start of the floating-rate period.

\subsection{Variation 2: Purchasing Power Parity Models}

A very different argument leading to the prescription of fixed exchange rates grows out of the modeling tradition associated with the monetary approaches to the balance of payments and exchange rates. In such frameworks, money prices adjust flexibly to clear markets and the law of one price holds for tradables. In this world, money is neutral and nominal exchange rate changes play no central allocative role. A variant of this class of model holds that while countries may produce different outputs, substitution elasticities are so high that we can aggregate all countries' outputs into a single goodan extreme form of elasticity optimism. In a sense, elasticities are too high rather than too low! In such a world, exchange rate adjustments cannot affect relative international prices. McKinnon (1984), for example, advocated fixed exchange rates coupled with "world monetarism" based on this type of model. Krugman (1991) has made an effective case against the approach. 
A variant of this argument is applied to developing countries; see, e.g., Calvo and Reinhart (2002). It is held that for many developing countries, pass-through to the general CPI is so rapid as to nullify the stabilizing benefits of flexible exchange rates.

\subsection{Variation 3: Real Wage Rigidity}

In the late 1970s economists argued that whereas United States labor markets were characterized by nominal wage rigidity, labor markets in Europe seemed tro be beset by real wage rigidity, one symptom of alleged "eurosclerosis." Branson and Rotemberg (1980) and Sachs (1980) provided Mundell-Fleming style model of macroeconomic policy under real wage rigidity, one with the implication that monetary policy would be ineffective under a floating exchange rate.

Assume that output supply is a function of a variable labor input and a fixed capital input, with firms' labor demand a decreasing function of the real product wage. On the other hand, union wage demands result in a constant real CPI wage. Demand for domestic output is a declining function of the real exchange rate defined in terms of the domestic output price, which itself is flexible and equates supply to demand. As is standard in the MundellFleming model, import prices are given in terms of foreign currency and adjust one-for-one with the exchange rate.

The result that monetary expansion is ineffective then follows. By raising import prices and hence the domestic CPI, a currency depreciation sparks higher nominal wage demands. The resulting incipient rise in the product wage would induce reduced supply by firms, so there is upward pressure on the domestic good's price and hence further upward pressure on the nominal wage. Equilibrium is restored when the nominal output price, nominal wage, and exchange rate, have all risen in proportion to the monetary expansion, leaving the real wage, real exchange rate, and real domestic output unperturbed. In short, the nominal wage rise nullifies any employment-expanding effect of a monetary expansion. Interestingly, the argument follows regardless of the size of the import share in domestic consumption. ${ }^{3}$

In the 1990s, the alleged rigidity of real wages in Europe provided one of the arguments for proceeding to a single currency. European labor markets,

\footnotetext{
${ }^{3}$ Fiscal expansion, in contrast, can be effective in raising output and employment. Because the domestic currency appreciates in order to crowd out foreign demand, the real product wage has room to decline even though the real CPI wage remains constant.
} 
it was argued, rendered monetary policy fairly ineffective anyway, so the cost of giving up national monetary policy levers would be low. In Obstfeld (1997) I discuss this argument in further detail and suggest that in the run up to the euro, there were still good reasons to attach gross costs to the surrender of national monetary autonomy. One should note also that the argument of real wage rigidity would apply to Europe as a whole, so that we might infer that from simple models of rigid real wages that the European Central Bank's monetary policy can be effective only through large-country effects. In practice things have worked differently. In aggregate the euro zone is less open than are the individual economies of its members, output prices are sticky, and the euro's steep depreciation after its launch did not induce anything close to a corresponding inflation in output prices. Moreover, most observers would judge the euro's slide to have allowed stronger European growth than would otherwise have occurred.

\subsection{Variation 4: Pricing to Market and Sunk Costs}

As the United States dollar depreciated from the heights attained in 1985, the U.S. current account initially deficit behaved perversely, widening for about two years before improving in a manner more consistent with standard theory. While economists subsequently concluded that nothing had really been amiss - see Krugman (1991) for further discussion - the 1985-87 experience nonetheless generated a spate of nonstandard theorizing that has enriched our view of the international adjustment process and of international price behavior.

In a seminal contribution, Dornbusch (1987) showed how strategic interactions among domestic producers and competing producers of imports could result in a muted response of import prices to exchange rate changes, at least compared to the full proportional response predicted by the Mundell-Fleming model's small country-cum-law of one price assumption. When markets are segmented - so that resale arbitrage is limited - producers of tradable goods may gain the ability to practice third-degree price discrimination, tailoring the prices they charge to individual market destinations. Under such pricing-to-market (PTM), a Japanese exporter to the U.S., faced with a yen appreciation against the dollar, might not raise the export's American dollar price pro tanto. Instead, it might choose to lower the yen price and thereby reduce it profit margin on U.S. sales so as to defend its U.S. market share. In this scenario, the good's dollar price for Americans rises by less than the 
dollar's depreciation against yen. The depreciation's effect on the relative price of Japanese imports and competing U.S. goods is thereby dampened. Empirical studies have convincingly demonstrated the prevalence of PTM behavior in manufacturing trade among OECD countries; see Goldberg and Knetter (1997). A stylized fact of this literature is that in response to a 10 percent depreciation of a target country's currency, exporters lower the export's own-currency price by around 5 percent in the same year. That is, the median pass-through of currency depreciation to manufacturing import prices tends to be around 50 percent over a one-year horizon.

It is important to keep in mind at this point the distinction between pass-through of exchange rate changes to import prices and pass-through to domestic import-competing goods' prices and the overall CPI. Other things equal, more extensive and rapid pass-through to import prices will enhance the expenditure-switching effects of an exchange rate change. In contrast, fuller and faster pass-through to domestic prices will reduce the expenditureswitching effects. Indeed, in the PPP models discussed as Variation 2 above, rapid pass-through to the entire range of goods in the CPI nullifies the exchange rate's potential expenditure switching role. Why might we expect rapid pass-though to import prices but slow pass-through to the CPI in response to a monetary shock? Because wage costs are a major component in production, and wages are both nominally sticky and (in normal conditions) very sluggish. Given this sluggishness in domestic-currency costs, output prices will inherit a tendency to respond sluggishly to monetary impulses, whereas exporters will face corresponding pressures to maintain the domestic-currency prices of their exports so as to maintain profit margins. Indeed, dynamic studies such as Campa and Goldberg (2001) suggest substantially complete long-run pass-through of exchange rate changes to import prices.

If PTM and partial pass-through are short-term phenomena, they can have only limited power to explain delayed adjustment to exchange rate changes. A second but related theoretical innovation of the late 1980s goes further in this regard. The literature on sunk costs and hysteresis in trade (for example, Baldwin and Krugman 1989 and Dixit 1989) predicts that the a large exchange rate change's trade effects will not be reversed merely by the unwinding of the exchange rate change. If exporting firms have incurred sunk costs to establish "beach heads" in the target country, an even larger exchange rate reversal may be needed before these firms reduce export supply and fully raise export prices. Once again, relative prices and trade flows may 
become less responsive to the exchange rate over some range. Such hysteretic effects, though doubtless present in reality, seem to have little bearing on the broad patterns of adjustment occasioned by large, persistent exchange rate swings.

The point to take home is that the theoretical advances of the late 1980s modify our view of the short-term adjustment to exchange rate changes, but leave pretty much intact our assessments of the longer term effects on the current account of permanent changes in monetary policy.

\subsection{Variation 5: PTM with Local Currency Pricing}

The literature on the New Open Economy Macroeconomics has allowed modelers to assess the implications of several forms of price and wage rigidity within fully specified dynamic general-equilibrium models. In open economies, nominal price rigidities can take various forms, and differences in pricing patterns can induce sharp alterations both in patterns of macroeconomic adjustment and in the welfare properties of monetary regimes.

One strand in the literature takes as its empirical starting point the empirical finding that for CPI real exchange rates, the tradable/nontradable distinction seems to carry little explanatory power: at least when nominal exchange rates are highly variable, relative international tradables prices move pretty much in line with relative international nontradables prices (Engel 1999). One possible interpretation of this result is that exporters not only price discriminate across markets, they also pre-set export prices in the buyer's currency and meet demand at the posted local-currency prices in the short run. With domestic prices also pre-set in the home currency, real CPI exchange rates and nominal exchange rates will be nearly perfectly correlated in the short run, as we indeed see in data from moderate-inflation countries. Chari, Kehoe, and McGrattan (2000) and Devereux and Engel (2000), among others, have explored models in which exporters effectively sell directly to consumers on the basis of PTM and local currency pricing (LCP).

LCP by exporters has important implications for the economy's adjustment to an exchange rate change. Suppose that a monetary expansion induces a currency depreciation. With import as well as domestic prices sticky, the currency change cannot switch domestic demand from imports to domestic goods. The main economic effects will be on the profits of domestic exporters. If they price their goods in foreign currency, the depreciation of 
the home currency raises their profits measured in domestic currency terms.

In the case of LCP we have exchange rate pessimism, not because of substitution between imports and domestic substitutes elasticities are small, but because the responses of import prices to exchange rates is assumed to be nil. In the next section I take up some of the policy implications of this view. I the explore alternative models that respect the empirical regularities stressed by Engel (1999), yet incorporate a significant expenditure switching role for exchange rates.

\section{$3 \quad$ Local Currency Pricing and its Implications}

New Open Economy Macro models with and without LCP can have strikingly different welfare implications. In this section I discuss the policy and empirical implications of some alternative models.

\subsection{Pricing in Buyer Currency: Simple Models}

Some models in the New Open Economy Macroeconomics assume that import prices are sticky in producer currency - the case of producer currency pricing (PCP). In principle such a formulation, coupled with some international market segmentation, could be consistent with PTM by exporters, who might set different producer-currency prices for goods destined for different markets. Such an approach would nonetheless imply a unitary short-run elasticity of import prices with respect to the exchange rate, so most models take the simpler tack of assuming the law of one price for imported goods, as in the Mundell-Fleming model.

Obstfeld and Rogoff (2000) develop a sticky-wage model along these lines and explore its implications for optimal monetary policy rules in the face of exogenous productivity shocks. In that model there are monopolistic distortions in labor and product markets, but monetary rules cannot offset these to raise welfare above its flexible-price level. The best that monetary policy can do is to achieve the flexible wage allocation associated with the realized values of the productivity shocks, which is constrained-efficient - that is, efficient subject to the monopoly distortions. (This result turns out to hold true not only when international policymakers cooperate in choosing their rules, but also in a Nash equilibrium.) In the flexible-wage equilibrium, a negative home relative productivity shock (holding world average productiv- 
ity constant) would require a fall in relative home output and a rise in its relative price. A home monetary contraction and an equal foreign expansion appreciate home currency, raising the price of home output to foreigners and lowering its price to home residents due to the PCP assumption. Thus, freely variable exchange rates support the constrained-optimal flexible-wage allocation even when wages are preset and sticky ex post.

These results must be modified when there are additional distortions in the world economy, as Obstfeld and Rogoff (2002) show. If the flexible-wage allocation is not constrained-efficient, it becomes possible for monetary rules to improve upon it by gearing them partially toward the extra distortions. In the Obstfeld-Rogoff (2000) model, international consumption risk sharing is perfect; the authors' 2002 paper allows for imperfect international risk sharing, which introduces an additional distortion alongside the sticky-wage distortion. Now, in a global cooperative equilibrium, optimal monetary rules no longer strive to replicate the flexible-wage allocation ex post. Instead, such rules depart from the latter allocation in order improve international risk sharing, and, depending on preference parameters, exchange rates can be more or less variable than under the flex-wage rules. (It is no longer the case, either, that cooperative and Nash rules coincide.) Goodfriend and King (2001) characterize monetary rules that replicate flexible-price equilibria ex post as delivering "price stability." Using their terminology, we might say that in these models, optimal monetary policy aims to produce nominal wage stability (rather than exchange rate stability) when wage rigidity is the only distortion. Otherwise, their can be a tradeoff between wage stability and other economic objectives. Benigno and Benigno (2001) illustrate other departures from price-stabilizing optimal policies under PCP and full arbitrage of markets for tradable goods. ${ }^{4}$

The model in Devereux and Engel (2000) departs from the preceding ones by assuming that exporters can price discriminate across home and foreign markets (PTM), and that they pre-set prices in the currency of the buyer (LCP). They also assume complete markets in contingent nominal payments. The model easily captures the regularity that movements in nominal and real CPI exchange rates are tightly correlated, because every country's CPI is pre-

\footnotetext{
${ }^{4}$ When each country has a multisector structure and shocks between domestic sectors are important, an exchange rate change, while efficient for handling purely country-specific shocks, can no longer gurantee the correct relative prices between domestic sectors. In this case of more targets than instruments, the value of exchange-rate flexibility may again be reduced. For a full discussion, see Tille (2002).
} 
set in its entirety, both the domestic and imported components. Another realistic implication is that there are deviations from the law of one price for tradables, deviations that are highly correlated with changes in nominal exchange rates. As in the preceding models, however, Devereux and Engel do not distinguish between the consumer prices of imported goods and the producer prices at which manufacturers of the imports sell their wares to domestic retailers. Thus, in the aggregate, every country faces temporarily rigid prices for domestic output in terms of imports.

If countries' imports are priced in local currencies, the implications for optimal monetary policies are drastic. First, exchange rate changes become powerless to alter the relative prices that domestic economic agents face. Thus, the important allocative role of flexible exchange rates in PCP models evaporates. Monetary policy simply cannot be used in general to attain the flexible-price allocation ex post. The exchange rate has no expenditureswitching power, so exchange rate pessimism is justified.

What role is there, then, for ex post exchange rate flexibility? The perhaps surprising answer is: possibly none. As Engel (2002) stresses, the model's complete nominal bond markets assumption makes international relative intertemporal marginal rates of substitution proportional to real exchange rate changes. To minimize ex post departures from true risk sharing (the complete risk sharing that a global planner could achieve if she could circumvent the barriers segmenting the two countries' goods markets), real exchange rate fluctuations should be minimized. There is no tradeoff between risk sharing and domestic stabilization, unlike in Obstfeld and Rogoff (2002), because the exchange rate is powerless to change the relative prices that economic actors face. Thus, welfare may be maximized when the nominal exchange rate is fixed.

More complex issues can arise when, unlike in the Devereux-Engel model, the disutility of labor effort is a strictly convex (rather than linear) function. In that case there is a tradeoff between global efficiency and exchange rate stability, since differential monetary stances can help to keep national marginal disutilities of labor effort in line with national productivity levels. I have been assuming until now that national monetary rules respond exclusively to productivity shocks, but if there is exogenous variability in foreign monetary policy, say, it may pay for the home country to adopt a flexible exchange rate so as to insulate itself from external inflationary shocks. The important message of this literature, however, is that the LCP model appears to deliver a stronger case for exchange-rate oriented monetary rules than do models 
assuming PCP, which instead suggest "benign neglect" of foreign exchange markets. ${ }^{5}$

Corsetti and Pesenti (2001) delve further into these questions. In their two-country model, producers sell domestic goods in home as well as foreign markets and potentially can practice price discrimination across borders. Specifically, the degree of pass-through of the exchange rate to export prices is indexed by a parameter $\eta$, such that $\eta=0$ corresponds to LCP and $\eta=1$ to PCP. Markets are incomplete (only noncontingent bonds are traded between countries) but it is the model's equilibrium implies that nominal consumption spending always equals nominal national revenue (so that current accounts are always zero). When $\eta=1$, the model is isomorphic to a dynamic version of the one in Obstfeld and Rogoff (2000) (without any nontradables), and so optimal monetary policy - in Nash as well as cooperative equilibria - entails replicating the flex-price equilibrium. When $\eta=0$, however, the flex-price equilibrium cannot be maintained and national welfare is maximized when exporters' revenues are stabilized in their own currencies (since then the markups on exports are minimized). In that case a fixed exchange rate is preferred (both in the Nash and cooperative scenarios, which obviously coincide). In the middle ground of partial exchange rate pass-through where $0<\eta<1$, there is a tradeoff between national revenue stabilization and attainment of the flex-price equilibrium, so exchange-rate movements are muted but not stopped. Here, as in the incomplete-markets case of Obstfeld and Rogoff (2002), there can be some scope for international monetary cooperation in choosing monetary policy rules, though its quantitative importance is likely to be small.

These results can be extended to throw light on the nature of optimum currency areas, as Corsetti and Pesenti (2002) illustrate. In an extension of their 2001 model, they allow producers to choose the pass-through percentage $\eta$ so as to maximize expected utility. ${ }^{6}$ Under national monetary rules that target the flexible-price allocation and thus entail exchange rate flexibility, it is optimal for firms to practice PCP, a choice that validates the regime of independent national currencies as optimal. If firms practice LCP, how-

\footnotetext{
${ }^{5}$ An interesting research direction is to look at the impact on policy rules and cooperation of international asymmetries in pricing behavior. Otani (2002) investigates international transmission in a hybrid model in which different countries' exporters may follow different invoicing practices for their foreign sales.

${ }^{6}$ Bacchetta and van Wincoop (2001) and Devereux and Engel (2001) also present general equilibrium analyses of the choice of exporters' currency of invoice.
} 
ever, authorities will find fixed exchange rates (or a single currency) optimal. Under these circumstances, however, firms will actually be indifferent to the choice of $\eta$ (after all, the exchange rate is credibly fixed, so it is irrelevant to pricing). It turns out that the national outputs are more highly correlated under the fixed-rate regime, as one might hope in comparing an OCA with a floating-rate system, but all countries' welfare is actually higher under the floating-rate arrangements. Since price setters would modify their strategies were authorities to drop fixed exchange rates in favor of an optimal float, an interesting question is whether fixed rates would be a subgame perfect Nash equilibrium regime. The Corsetti-Pesenti analysis implies that it would not pay for a lone monetary authority unilaterally to defect from a fixed rate regime (given that partner countries continue to peg). In an equilibrium where policy authorities cooperate to choose the regime, however, countries would move to floating rates. It is simply not credible for price-setters to "threaten" to retain LCP if exchange rates are allowed to float.

\subsection{Are the Simplest Models Reliable Guides for Pol- icy?}

The models I have discussed are illuminating and intriguing. They well illustrate how a careful framework built on microfoundations can discipline and inform macroeconomic policy evaluation in a way that simple IS-LM style models simply cannot. The latter models simply make no attempt to ensure the consistency of macroeconomic relationships and welfare criteria.

One must still be extremely cautious, however, in drawing policy conclusions from specific,and in some cases very special, models. If one takes seriously the LCP models described in the last section, one might conclude in favor of fixed exchange rate regimes. These models miss at least two critical aspects of reality, however:

- Import prices paid at the point of entry to a country display very different behavior from the CPI prices of imported goods. Thus, regularities applying to CPI real exchange rates may have little bearing on import price behavior.

- It may be firms rather than consumers whose decisions are central to the expenditure switching effect of the exchange rate. In that case import prices at the point of entry will influence economic decisions. 
Particularly when firms have multinational operations, the critical relative price for expenditure switching will be the real exchange rate measured with respect to relative nominal unit labor costs.

\subsubsection{Prices in International Trade}

The extreme assumption of LCP models that the short-run pass-through from exchange rates to import prices is nil helps rationalize the observed behavior of real CPI exchange rates. But prices at earlier stages of importation behave quite differently from CPI prices. As I have noted, most studies of import or export prices show considerable pass-through (with 50 percent the median figure) over a one-year horizon. Once imports reach the consumer, however, they incorporate a substantial nontradable marketing input, and, moreover, may pass through imperfectly competitive retailing networks so that the link between consumer and original price is weakened further. Corsetti and Dedola (2002) present a formal model along these lines, although they assume that retailing is competitive.

Direct evidence on invoice currencies in trade seems to contradict the LCP assumption for import prices. For most countries - the United States is an outstanding exception here, as probably is the euro zone by now - imports are mostly invoiced in foreign currencies. There is also some tendency, though weakening over time, for "Grassman's law" to hold, that is, exports are invoiced in the exporter's currency. For the United States, 81 percent of imports and 92 percent of exports were invoiced in the home currency, the U.S. dollar, in 1995. For some other countries the respective import and export shares of domestic currency for 1995 were: Japan (23,36); Germany $(52,75)$; France $(49,52)$; United Kingdom $(43,62)$; Italy $(37,40)$; Netherlands $(43,44) .{ }^{7}$ However, invoicing considerations are only part of the story, since the stickiness of import and export prices, however invoiced, may differ from that of retail prices.

In general import prices, measured in the currency of the country of origin, will be closely linked to nominal wages at the production point, which themselves adjust quite slowly. On the other hand, import prices will be reasonably responsive to exchange rates, though often not to the extent that they exhibit full short-run pass-through. Thus, a currency depreciation will tend to worsen the terms of trade of the depreciating country by lowering its

\footnotetext{
${ }^{7}$ These data are reported by Bekx (1998), table 4 .
} 
relative wage. The evidence shows that this pattern indeed appears strongly in the data (see Obstfeld and Rogoff 2000 and Obstfeld 2001), whereas the LCP models discussed above, taken literally, do not imply that currency depreciation worsens one's terms of trade. Because wages move more slowly than prices in international trade, pass-through to import prices should also be more rapid than pass-through to the general CPI, implying that nominal depreciation causes real depreciation.

\subsubsection{Economic Effects of Exchange Rate Changes}

But do these changes in real relative prices induce economic agents to switch demand between domestic and foreign goods? Even if exchange rates do not affect the relative prices consumers face, the answer is yes provided firms respond.

One development suggesting that firm responses are important is the increasing importance of international outsourcing and trade in intermediate products. Feenstra (1998) and Hummels, Ishii, and Yi (2000) document the trends.

Obstfeld (2001) develops a model in which retailing firms can switch between imported and domestic inputs, with their relative price depending on the relative (pre-set) wages levels at home and abroad. ${ }^{8}$ On the other hand, retailing forms pre-set the prices of the final consumer goods in terms of home currency, and it is prohibitively costly for consumers to arbitrage between national markets. In this setup, exchange rate movements have important expenditure switching effects and optimal monetary policy targets the flexible wage and price allocation. While the model captures the high empirical correlation between the nominal and real CPI exchange rates, the stickiness of final-goods prices actually is irrelevant to the realized allocation, so that real CPI exchange rate volatility is irrelevant as well. In its strong form, this result is due to rather special assumptions (for example, all final consumption is nontradable, complete home bias in equity holdings, law of one price for intermediate tradables). ${ }^{9}$

A closely related channel comes from firm's sourcing decisions. Increasingly over the postwar period, large corporations have established manufacturing facilities across the globe. One important motivation for doing so is

\footnotetext{
${ }^{8}$ McCallum and Nelson (2000) present an alternative open economy model based on trade in intermediates.

${ }^{9}$ See Obstfeld (2002) for further discussion.
} 
diversification. Given stickiness in nominal wages, a currency depreciation will lower the depreciating country's relative costs and make it relatively attractive to shift production there.

Intrafirm trade is a significant part of overall international trade. Rangan and Lawrence (1999, p. 2) report that in 1994, "more than 35 percent of U.S. exports and almost 43 percent of U.S. imports represented the intrafirm transactions of U.S.- and foreign-headquartered multinational enterprises." How does this circumstance affect the trade response to exchange rate changes? Some have argued that intrafirm transactions may be unresponsive to normal economic incentives. A counter-argument, however, is that the presence of production facilities in different countries enhances the international flow of information within the firm, allowing it to respond more nimbly to international price changes by shifting activities across borders. Rauch and Trindade (2002) develop a formal model in which enhanced information networks increase trade elasticities; see also Grossman and Helpman (2001). ${ }^{10}$ Rangan and Lawrence (1999) provide evidence that intrafirm trade responds strongly to exchange rate changes. Figure 1, which is taken from Rangan and Lawrence (1999, p. 89), shows that in the dollar's 1985-89 depreciation episode, U.S. multinationals foreign affiliates around the world increased their U.S. content shares, with the possible exception of Asian developing countries, where there was anyway a strong trend of local content augmentation. ${ }^{11}$ In any case the positive correlation between the dollar's real depreciation and U.S. content increase is striking. The results indicate substantial expenditure switching by firms involved in international trade.

\subsubsection{Some Further Evidence}

This section takes a very brief look at some new and updated evidence on international prices. Other papers, including Dornbusch (1987) and my own work, both with Rogoff (2000) and alone (2000), have looked at related evidence, though here I follow Dornbusch in looking at somewhat disaggregated data. I take advantage of the detailed data collected by the governments of

\footnotetext{
${ }^{10}$ It would be an important extension of the New Open Economy Macroeconomics approach to build directly into economic models the kinds of matching and contracting problems that these authors emphasize. Such an extension might also allow one to endogenize certain asset-market imperfections.

${ }^{11}$ I am grateful to Subi Rangan and Bob Lawrence for providing the data underlying Figure 1.
} 
Canada and the United States. The findings support the contention that exchange rate changes alter relative international prices in conventional ways, although the work is preliminary and suggests interesting areas for future inquiry.

Table 1 reports correlations between the nominal exchange rate and the relative export price index using Canadian and U.S. 1-digit SITC categories of exports. All data are monthly. ${ }^{12}$ Under LCP a country's exports would be priced in the destination market currency and it is not obvious that a nominal exchange rate change would enhance the depreciating country's competitiveness by lowering the relative price of its exports (see Obstfeld and Rogoff 2000). Using either end-of-month or month-average exchange rates, however, one reaches the conclusion that a nominal depreciation of the Canadian dollar against the U.S. dollar is associated with a fall in the relative price of Canadian exports. Figures 2 through 9 illustrate the results in graphical form for twelve-month log changes. (In Figures 2 through 9, positive changes indicated by the broken line are depreciations of the U.S. relative to the Canadian dollar and positive changes indicated by the solid line are increases in the relative price of Canadian relative to U.S. exports.) Both the correlation coefficients and the figures suggest considerable heterogeneity among industrial categories, with some tendency for a lower correlation for agricultural and natural resource products. The differences across SITC categories deserve further theoretical and empirical study.

Another relative price that the exchange rate might affect is that between imports and import competing goods. For Canada, Figures 10 through 16 show (in levels) the ratio of Canadian import prices to the industrial prices of competing domestic goods since 1992. ${ }^{13}$ Particularly for industrial goods and textiles, there is a clear tendency for a nominal effective depreciation of the Canadian dollar (increase in the dashed line) to raise relative import prices (increase in the solid line).

\subsubsection{The Answer}

The consumer prices of imports certainly appear to be sticky in local currency. A broad consideration of the evidence gives no basis, however, for rad-

\footnotetext{
${ }^{12}$ Disaggregated Canadian data come from the CANSIM database, whereas U.S. data, matched by SITC, are from the BLS. Exchange rates are from IMF and Global Financial Data.

${ }^{13}$ Industrial and import price data are from CANSIM.
} 
ically rethinking the view that exchange rates have significant expenditureswitching effects in open economies. Indeed, for many purposes it is not a very misleading short cut to abstract from distribution channels and assume that consumer import prices respond directly to exchange rates.

\section{Conclusion}

In this paper I have argued that the limited pass-through of exchange rate changes to consumer import prices does not lead to the conclusion that optimal policy regimes should sharply limit exchange rate movements. Two factors (at least) can sharply modify the conclusions of the simplest macroeconomic models based on local currency pricing. One is the chain of transactions linking import prices at the point of entry to the ultimate prices consumers pay. Another is the important role of firm sourcing decisions in a world of globalized production. Richer models that incorporate these empirically relevant features point to an important role for the exchange rate in switching expenditure between countries. The New Open Economy Macroeconomics provides an ideal setting in which to explore these questions.

The preceding conclusions can break down for very open economies or in conditions in which nominal wages and prices become flexible. Notwithstanding the technological and organizational factors that are effectively reducing

economic distance day by day, the larger industrial currency areas remain insular enough that exchange rate changes seem likely to remain effective into the foreseeable future. 


\section{References}

Bacchetta, Philippe and van Wincoop, Eric. "A Theory of the Currency Denomination of International Trade." Mimeo, Studienzentrum Gerzensee and University of Virginia, 2001.

Baldwin, Richard and Krugman, Paul R. "Persistent Trade Effects of Large Exchange Rate Shocks." Quarterly Journal of Economics 104 (November 1989), pp. 635-654.

Bekx, Peter. "The Implications of the Introduction of the Euro for non-EU Countries." Euro Papers 26, European Commission, July 1998.

Benigno, Gianluca and Benigno, Pierpaolo. "Price Stability in Open Economies." Mimeo, Bank of England and New York University, 2001.

Blejer, Mario I.; Khan, Mohsin S.; and Masson, Paul R. "Early Contributions of Staff Papers to International Economics." IMF Staff Papers 42 (December 1995), pp. 707-733.

Branson, William H. and Rotemberg, Julio J. "International Adjustment with Wage Rigidity." European Economic Review 13 (May 1980), pp. 309332.

Calvo, Guillermo A. and Reinhart, Carmen M. "Fear of Floating." Quarterly Journal of Economics 117 (May 2002), pp. 379-408.

Campa, José Manuel and Goldberg, Linda A. "Exchange Rate Pass-Through into Import Prices: A Macro or Micro Phenomenon?" Mimeo, IESE Business School and Federal Reserve Bank of New York, 2001.

Chari, V. V.; Kehoe, Patrick J.; and McGrattan, Ellen R. "Can Sticky Price Models Generate Volatile and Persistent Real Exchange Rates?" Federal Reserve Bank of Minneapolis Research Department Staff Report 277, August 2000 .

Corsetti, Giancarlo and Dedola, Luca. "Macroeconomics of International Price Discrimination." Mimeo, University of Rome III and Bank of Italy, 2002.

Corsetti, Giancarlo and Pesenti, Paolo. "International Dimensions of Optimal Monetary Policy." Mimeo, University of Rome III and Federal Reserve Bank of New York, 2001.

. "Self-Validating Optimum Currency Areas." Mimeo, Uni$\overline{\text { versity }} \overline{\text { of Rome }}$ III and Federal Reserve Bank of New York, 2002.

Devereux, Michael B. and Engel, Charles. "Monetary Policy in the Open Economy Revisited: Price Setting and Exchange Rate Flexibility." Working Paper 7665, National Bureau of Economic Research, April 2000. 
. "Endogenous Currency of Price Setting in a Dynamic Open $\bar{E} \bar{c} \bar{n} \overline{-} \bar{y} \bar{y} \bar{M} \overline{o d e l} . "$ Working Paper 8559, National Bureau of Economic Research, October 2001.

Dixit, Avinash K. "Hysteresis, Import Penetration, and Exchange Rate PassThrough." Quarterly Journal of Economics 104 (May 1989), pp. 205-228.

Dornbusch, Rudiger. "Exchange Rates and Prices." American Economic Review 77 (March 1987), pp. 93-106.

Engel, Charles. "Accounting for U.S. Real Exchange Rate Changes." Journal of Political Economy 107 (June 1999), pp. 507-538.

"The Responsiveness of Consumer Prices to Exchange $\bar{R} \overline{\text { ates }}$ and $\overline{\mathrm{t}} \overline{\mathrm{T}}$ Implications for Exchange-rate Policy: A Survey of a Few Recent New Open-Economy Macro Models." Working Paper 8725, National Bureau of Economic Research, January 2002.

Feenstra, Robert C. "Integration of Trade and Disintegration of Production in the Global Economy." Journal of Economic Perspectives 12 (Fall 1998), pp. 31-50.

Goldberg, Pinelopi Koujianou and Knetter, Michael M. "Goods Prices and Exchange Rates: What Have We Learned?" Journal of Economic Literature 35 (September 1997), pp. 1243-1272.

Goodfriend, Marvin and King, Robert G. "The Case for Price Stability." Working Paper 01-02, Federal Reserve Bank of Richmond, April 2001.

Grossman, Gene M. and Helpman, Elhanan. "Outsourcing in a Global Economy." Mimeo, Princeton University and Harvard University, 2001.

Hummels, David; Ishii, Jun: and Yi, Kei-Mu. "The Nature and Growth of Vertical Specialization in World Trade." Journal of International Economics 54 (June 2000), pp. 75-96.

Krugman, Paul R. "Has the Adjustment Process Worked?" in International Adjustment and Financing: The Lessons of 1985-1991, edited by C. Fred Bergsten. Washington, D.C.: Institute for International Economics, 1991.

McCallum, Bennett T. and Nelson, Edward. "Monetary Policy for an Open Economy: An Alternative Framework with Optimizing Agents and Sticky Prices." Oxford Review of Economic Policy 16 (Winter 2000), pp. 74-91.

Machlup, Fritz. "Elasticity Pessimism in International Trade." Economia Internazionale 3 (February 1950), pp. 118-141.

McKinnon, Ronald I. An International Standard for Monetary Stabilization. Washington, D.C.: Institute for International Economics, 1984 
Metzler, Lloyd A. "The Theory of International Trade," in A Survey of Contemporary Economics, edited by Howard S. Ellis. Philadelphia: Blakiston, 1948.

Obstfeld, Maurice. "Europe's Gamble." Brookings Papers on Economic Activity, 2:1997, pp. 241-317.

- "International Macroeconomics: Beyond the Mundell-Fleming $\overline{\text { Model. }} \overline{\text { I }} \bar{I} \bar{M} \bar{F} \bar{S}$ taff Papers 47 (Special Issue 2001), pp. 1-39.

$\bar{V} \overline{\text { olatility."}} \overline{-} \overline{\text { American Economic Review } 92 \text { (May 2002), in press. }}$

Obstfeld, Maurice and Rogoff, Kenneth. "New Directions for Stochastic Open Economy Models." Journal of International Economics 50 (February 2000), pp. 117-153.

. "Global Implications of Self-Oriented National Monetary $\overline{\mathrm{R}} \overline{\mathrm{ul}} \overline{\mathrm{es}} \overline{\mathrm{O}} \overline{\mathrm{Q}} \overline{\mathrm{Q}} \overline{\mathrm{u}} \overline{\mathrm{r} t} \overline{\mathrm{e}} \mathrm{rly}$ Journal of Economics 117 (May 2002), pp. 503-535.

Orcutt, Guy H. "Measurement of Price Elasticities in International Trade." Review of Economics and Statistics 32 (May 1950), pp. 117-132.

Otani, Akira. "Pricing-to-Market (PTM) and the International Transmission Effect of Monetary Policy: The New Open-Economy Macroeconomics Approach." IMES Discussion Paper Series 2002-E-5, Bank of Japan, May 2002.

Rangan, Subramanian and Lawrence, Robert Z. A Prism on Globalization: Corporate Responses to the Dollar. Washington, D.C.: Brookings Institution, 1999.

Rauch, James E. and Trindade, Vitor. "Information, International Substitutability, and Globalization." Mimeo, University of California, San Diego, and Syracuse University, 2002.

Sachs, Jeffrey D. "Wages, Flexible Exchange Rates, and Macro-Economic Policy." Quarterly Journal of Economics 94 (November 1980), pp. 731-747.

Tille, Cédric. "How Valuable Is Exchange Rate Flexibility? Optimal Monetary Policy under Sectoral Shocks." Mimeo, Federal Reserve Bank of New York, 2002.

Tinbergen, Jan. An Econometric Approach to Business Cycle Problems. Paris: Hermann, 1937. 
Table 1

Correlations between relative export price and nominal exchange rate (Canada-US)

Sample Period: 1993:03-2001:03

\begin{tabular}{lcc}
\hline \hline Category & Period Average & End-of-Month \\
\hline Food and live animals & 0.16 & 0.27 \\
Beverages and tobacco & 0.14 & 0.15 \\
Crude materials, except fuels, inedible & 0.22 & 0.29 \\
Mineral fuels, lubricants and related materials & 0.36 & 0.30 \\
Chemicals & 0.38 & 0.40 \\
Manufactured goods, classified chiefly by material & 0.28 & 0.33 \\
Machinery and transport equipment & 0.84 & 0.81 \\
Miscellaneous manufactured articles & 0.91 & 0.91 \\
\hline \hline
\end{tabular}

Note: Correlations are defined so that a positive number implies that the price of U.S. exports relative to Canadian exports tends to rise when the Canadian dollar depreciates relative to the U.S. dollar. 


\section{Figure 1}

Changes in real exchange rates and U.S. content levels in sales made by majority-owned foreign affiliates of U.S. multinationals, selected economies, 1985-89

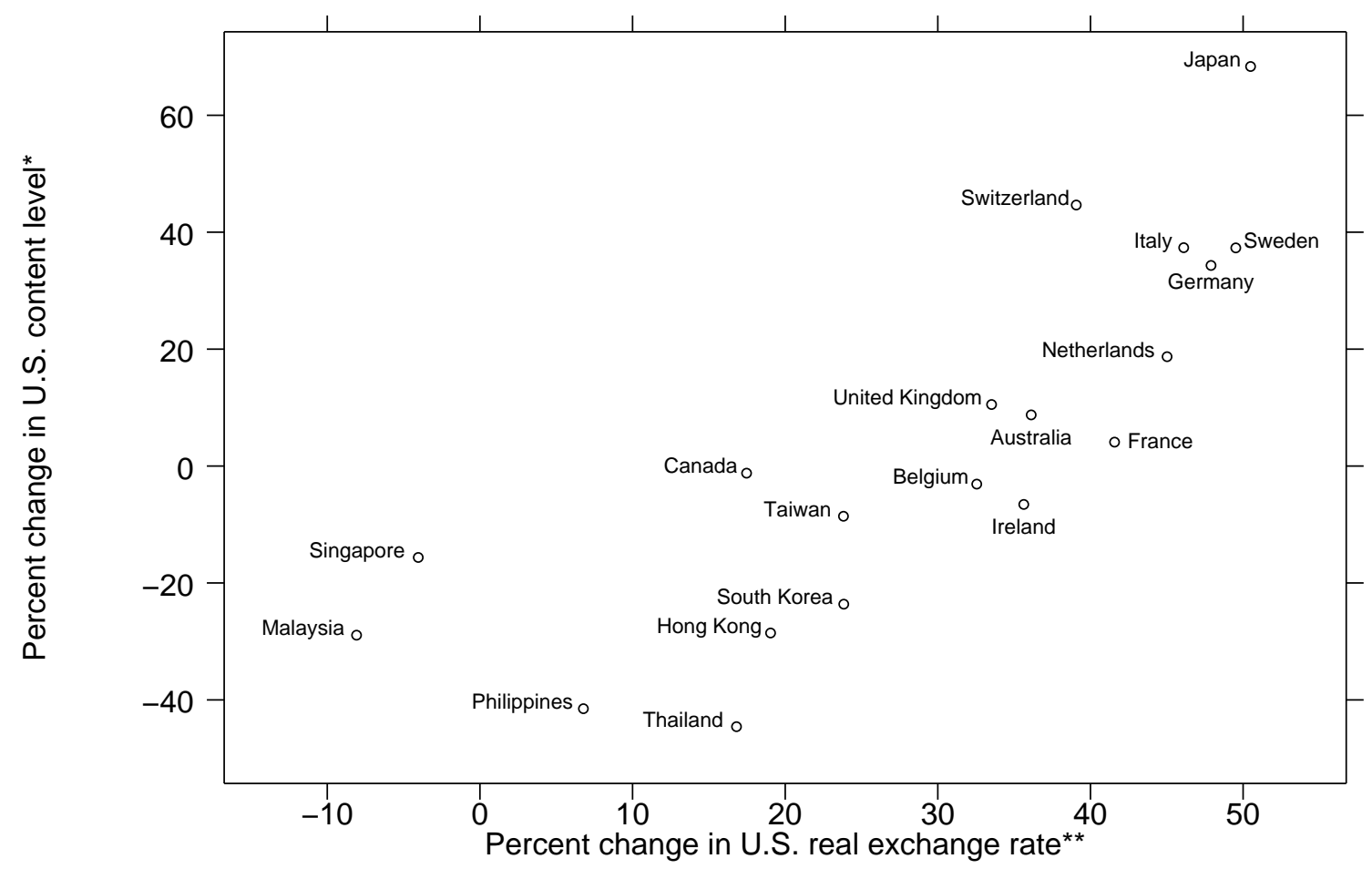

Source: Rangan and Lawrence (1999, p. 89)

* The percentage change in U.S. content levels between 1985 and 1989 is the change in the share of U.S. content in sales made by majority-owned foreign affiliates of U.S. multinational parents.

** The U.S. real exchange rate is denominated as U.S. dollars per foreign currency units; therefore positive (negative) changes between 1985 and 1989 represent a depreciation (appreciation) in the real exchange value of the dollar. 
Figure 2

Relative Canada-US export price and bilateral exchange rate movements

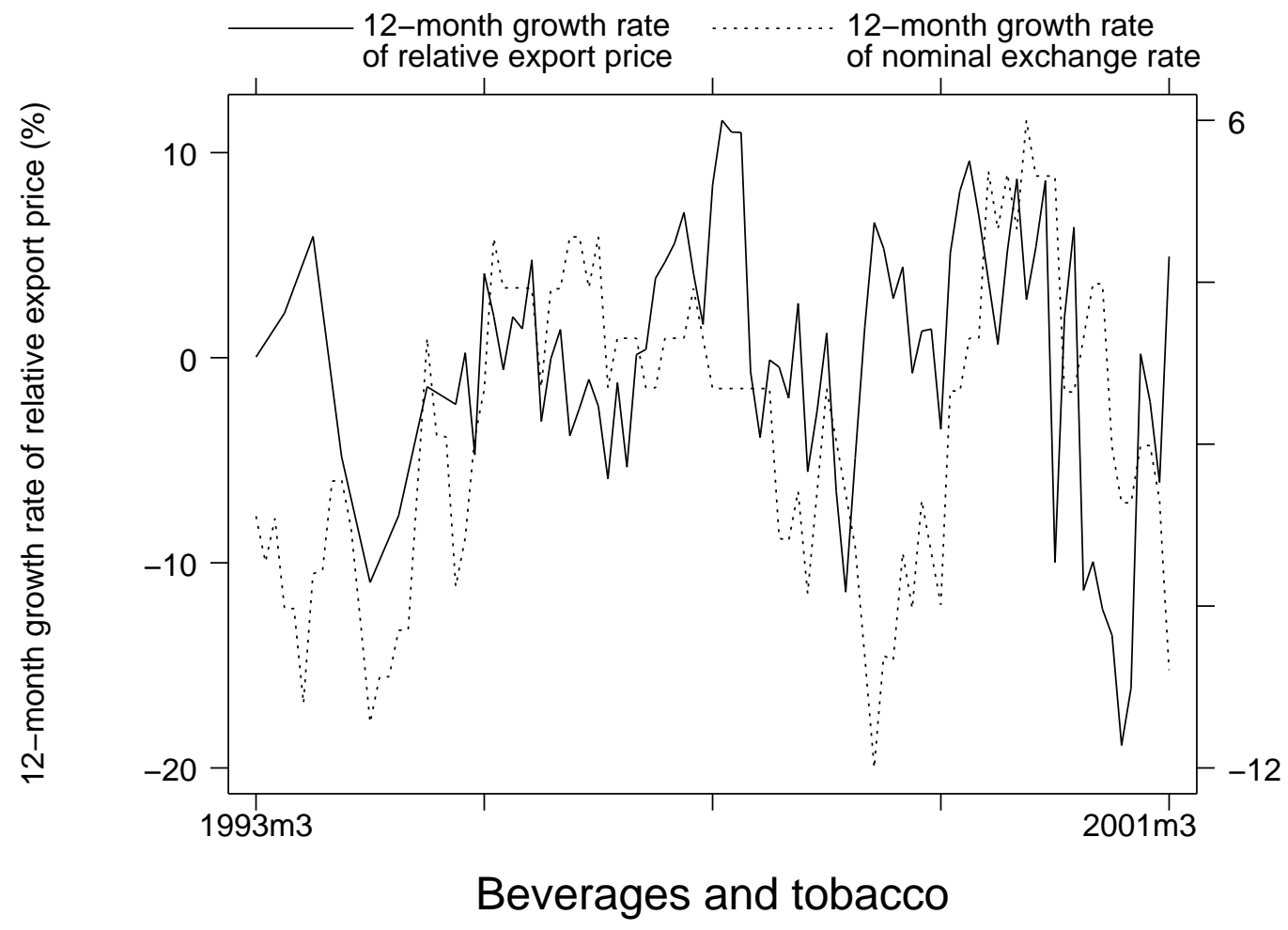


Figure 3

Relative Canada-US export price and bilateral exchange rate movements

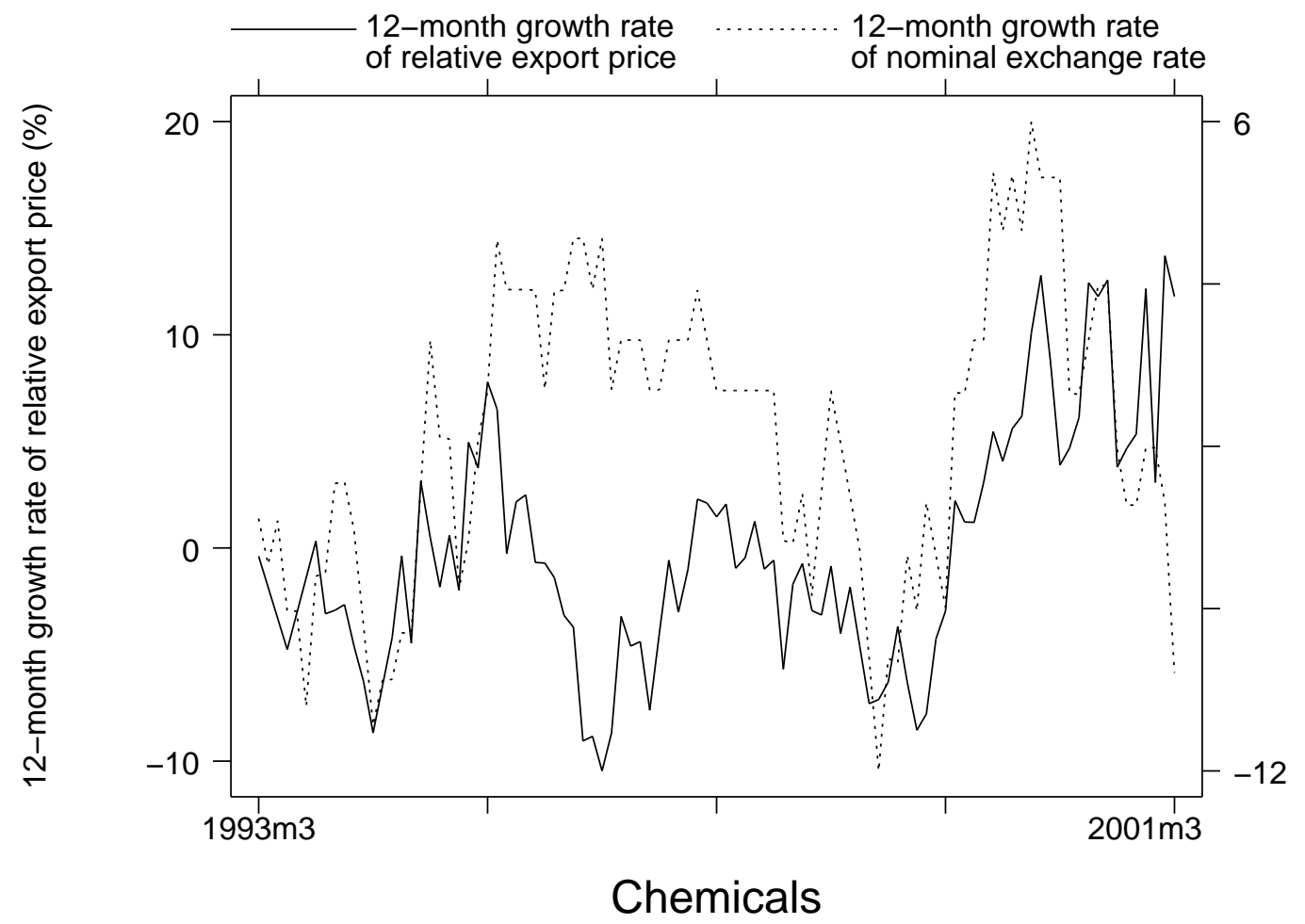

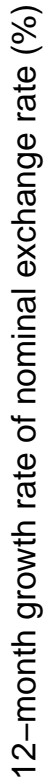

Chemicals 
Figure 4

Relative Canada-US export price and bilateral exchange rate movements

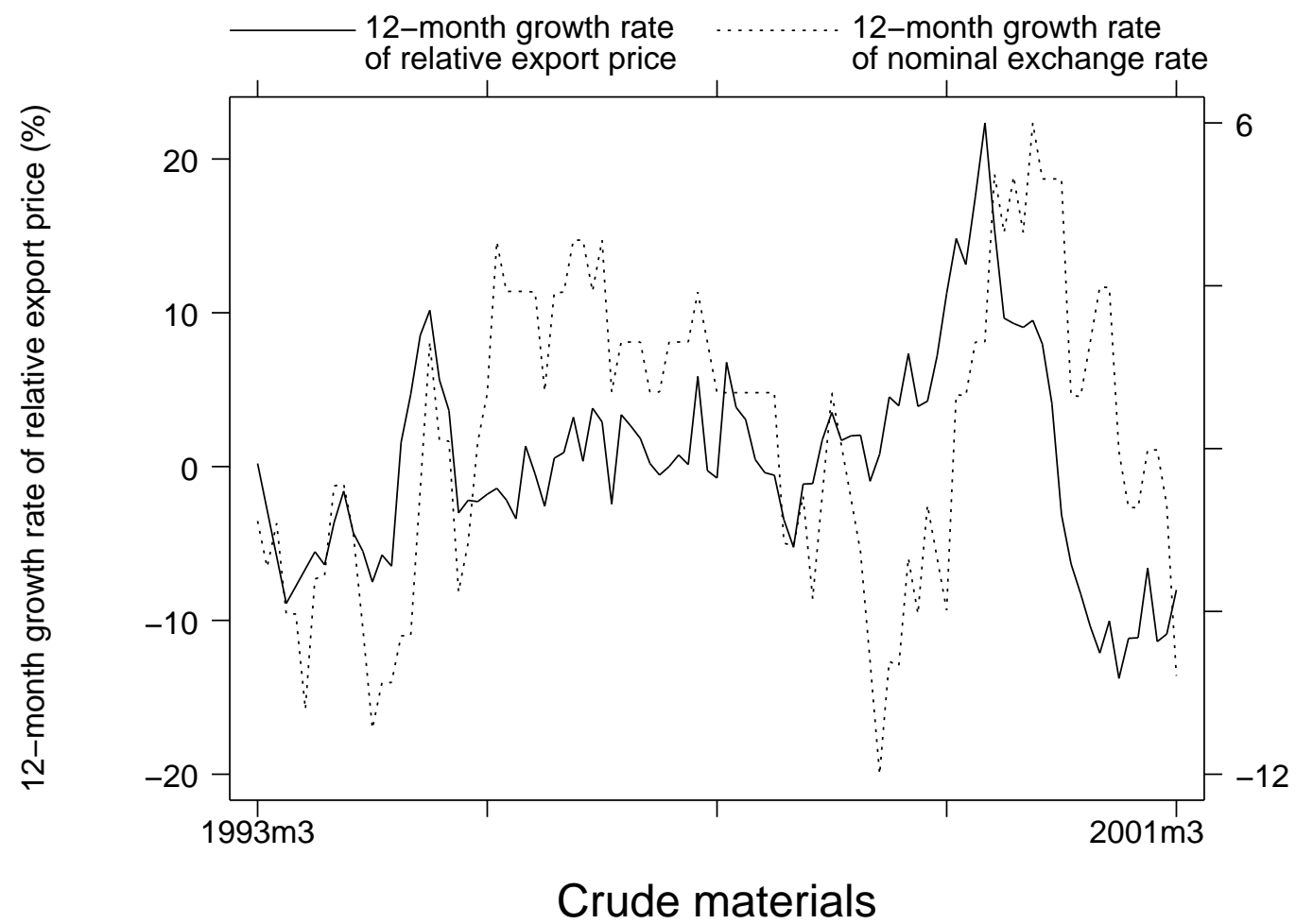

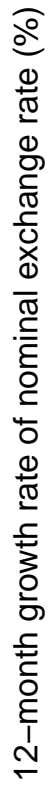

Crude materials 
Figure 5

Relative Canada-US export price and bilateral exchange rate movements

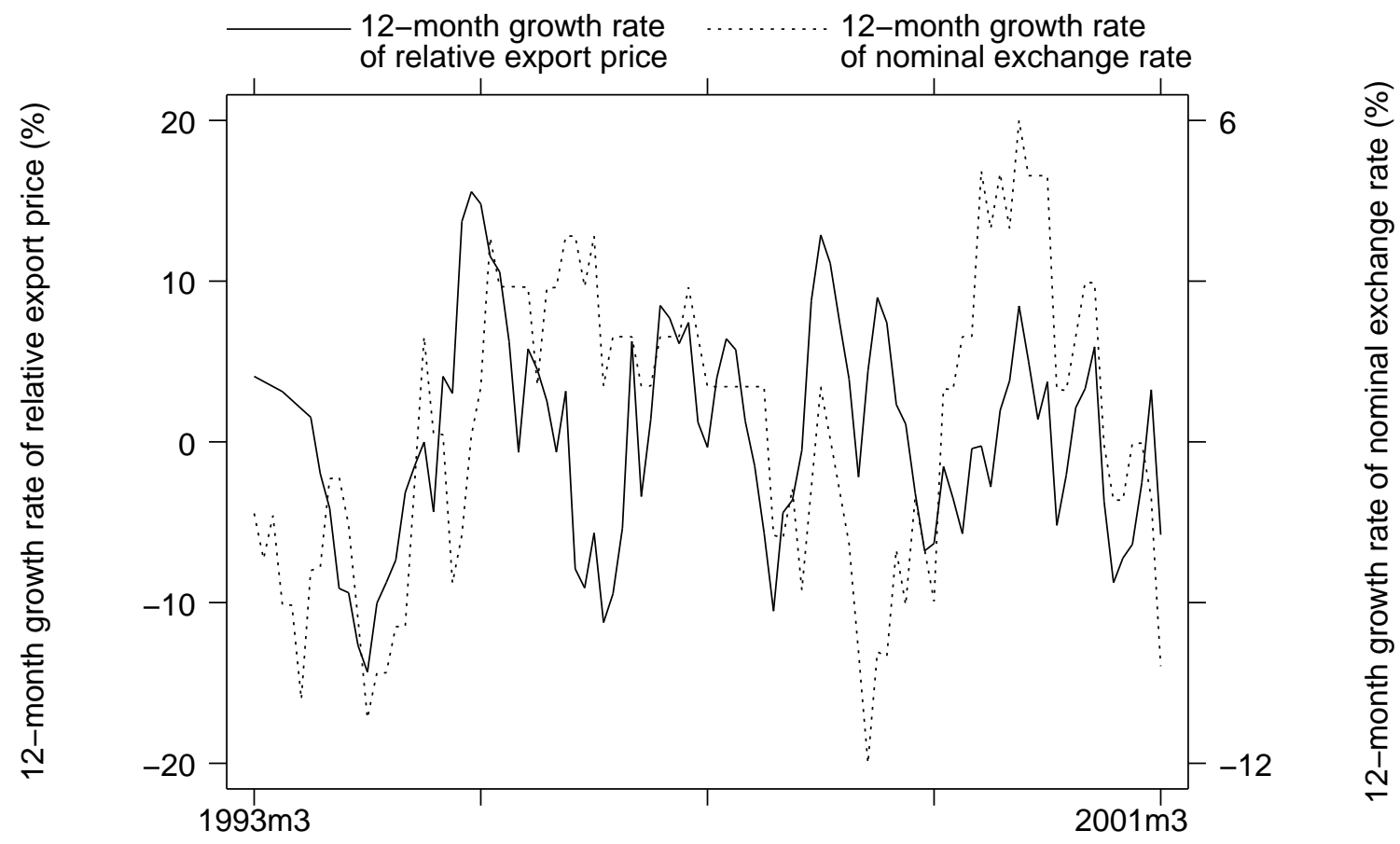

Food and live animals 
Figure 6

Relative Canada-US export price and bilateral exchange rate movements

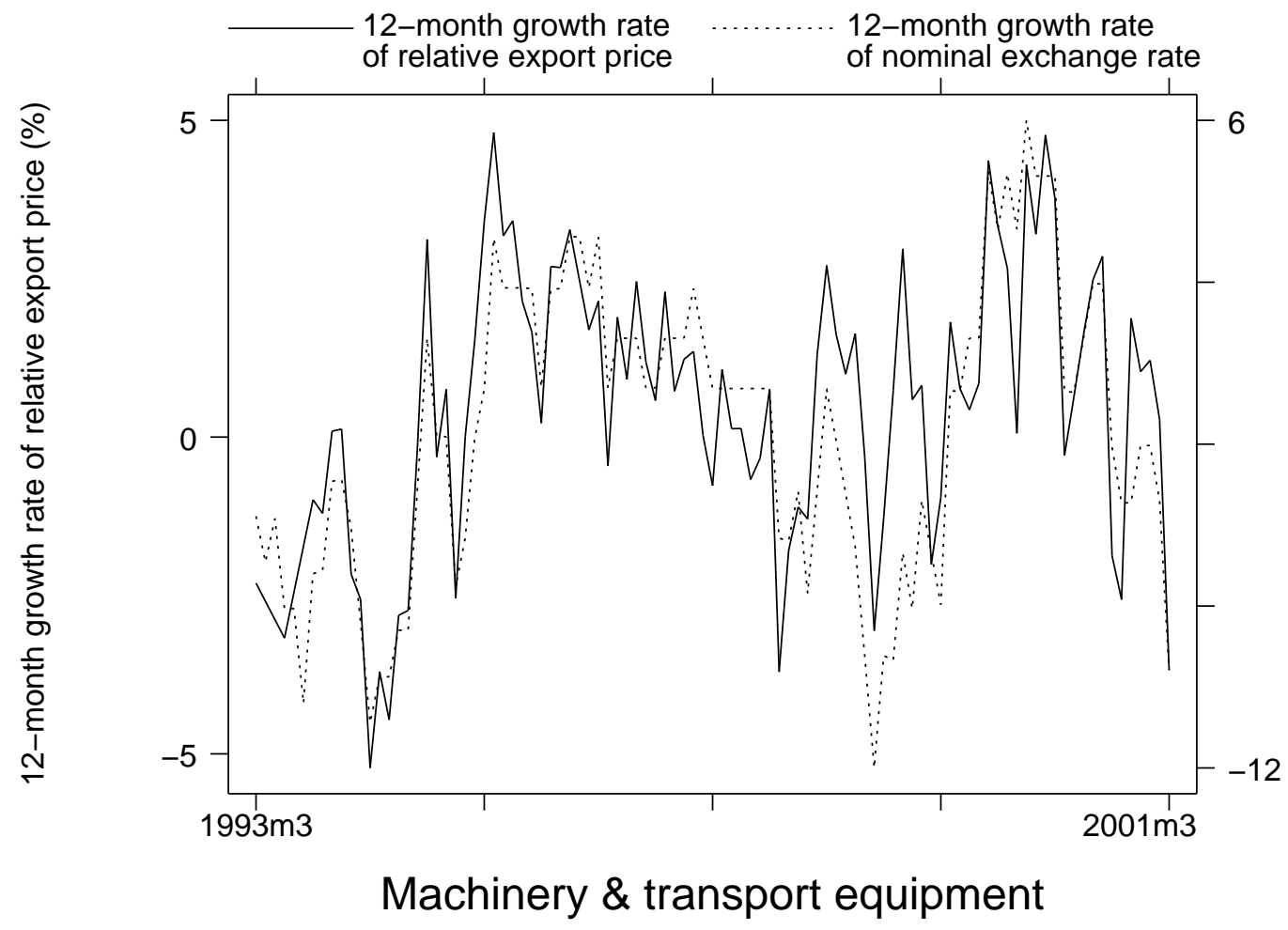

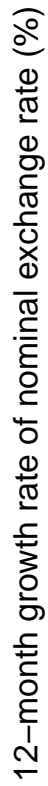

Machinery \& transport equipment 
Figure 7

Relative Canada-US export price and bilateral exchange rate movements

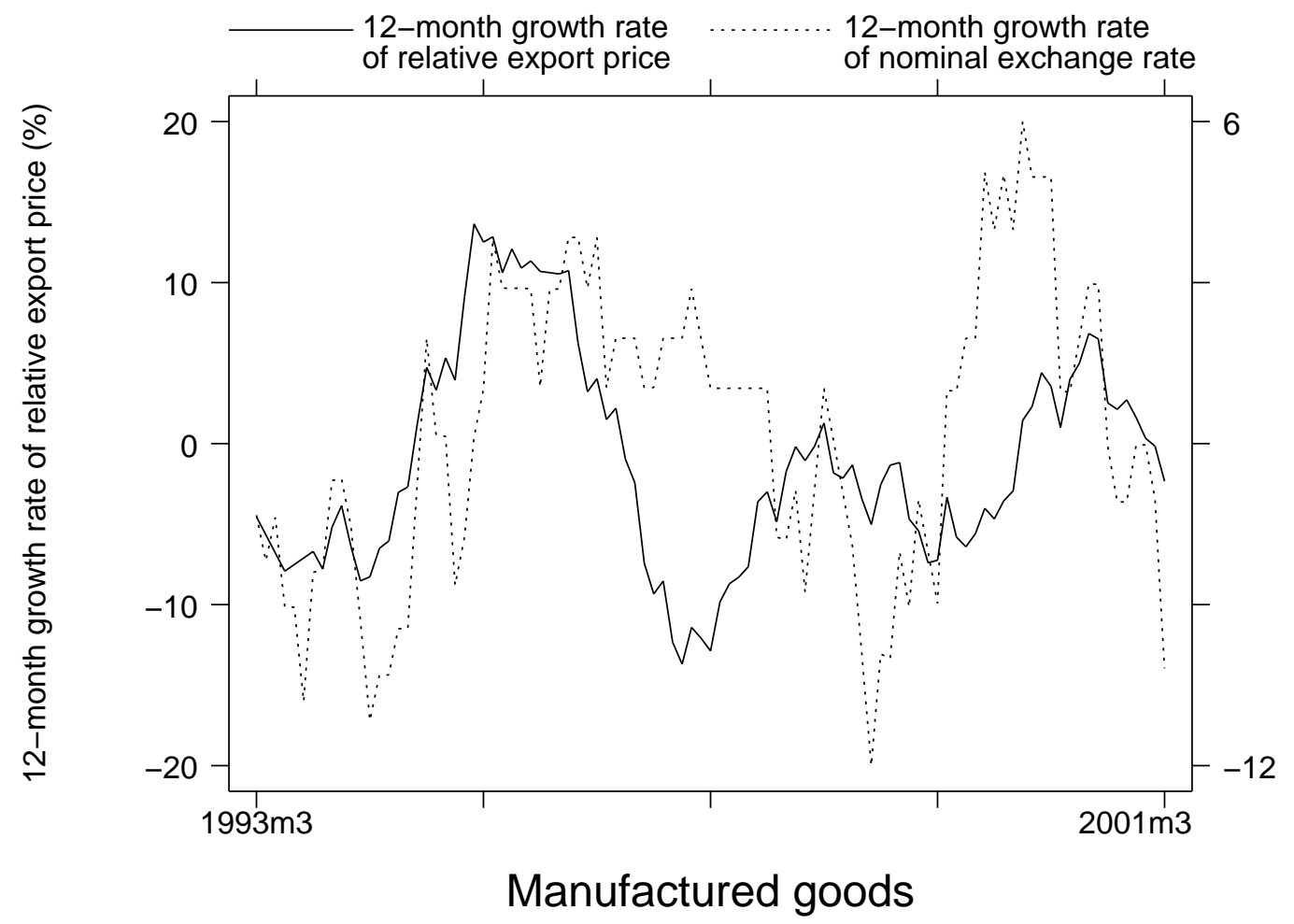

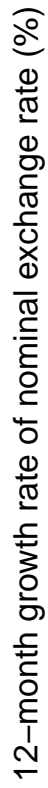


Figure 8

Relative Canada-US export price and bilateral exchange rate movements

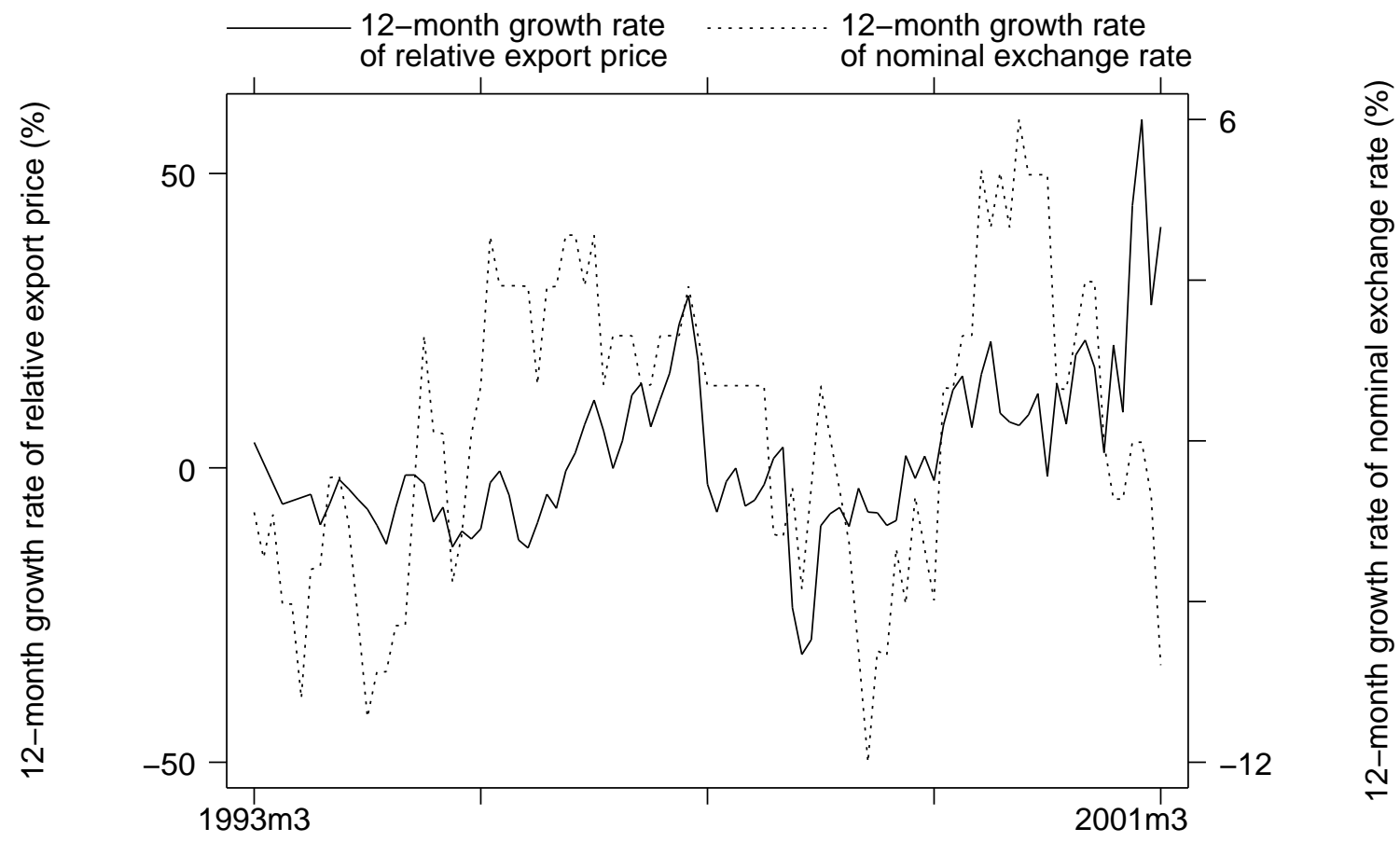

Mineral fuels, lubricants, etc. 
Figure 9

Relative Canada-US export price and bilateral exchange rate movements

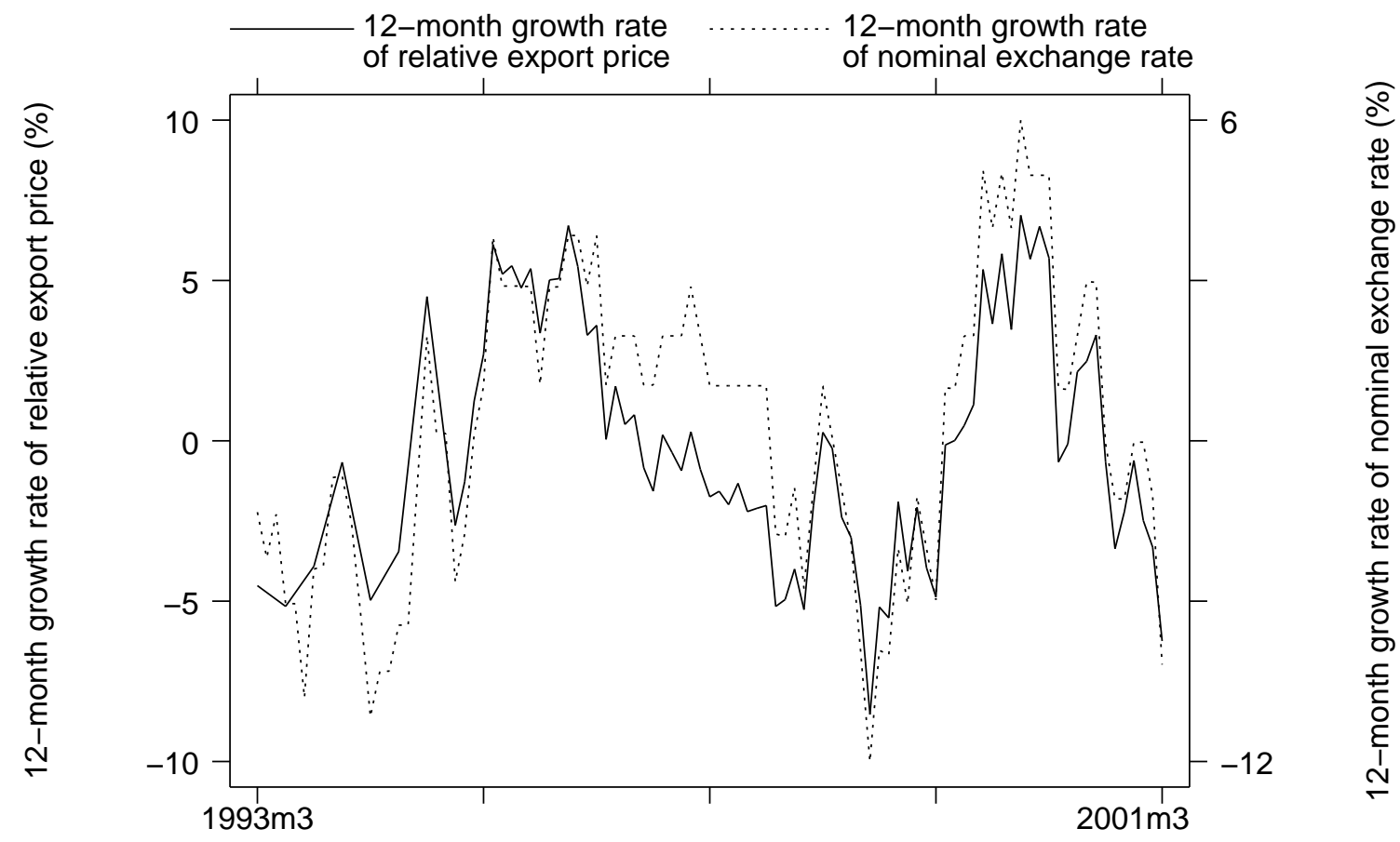

Misc. manufactured articles 
Figure 10

Import-industrial price ratio and nominal effective exchange rate movements

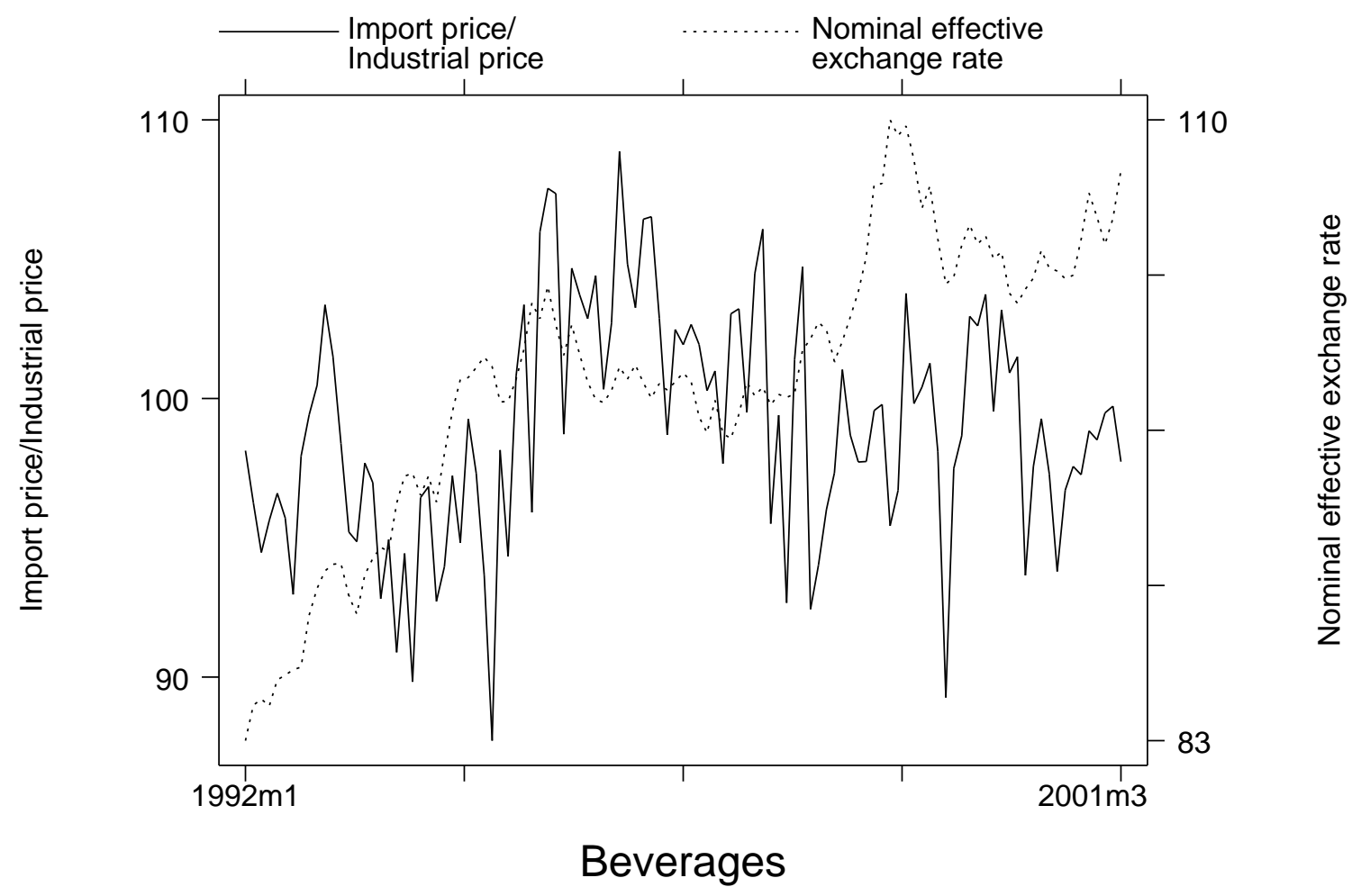


Figure 11

Import-industrial price ratio and nominal effective exchange rate movements

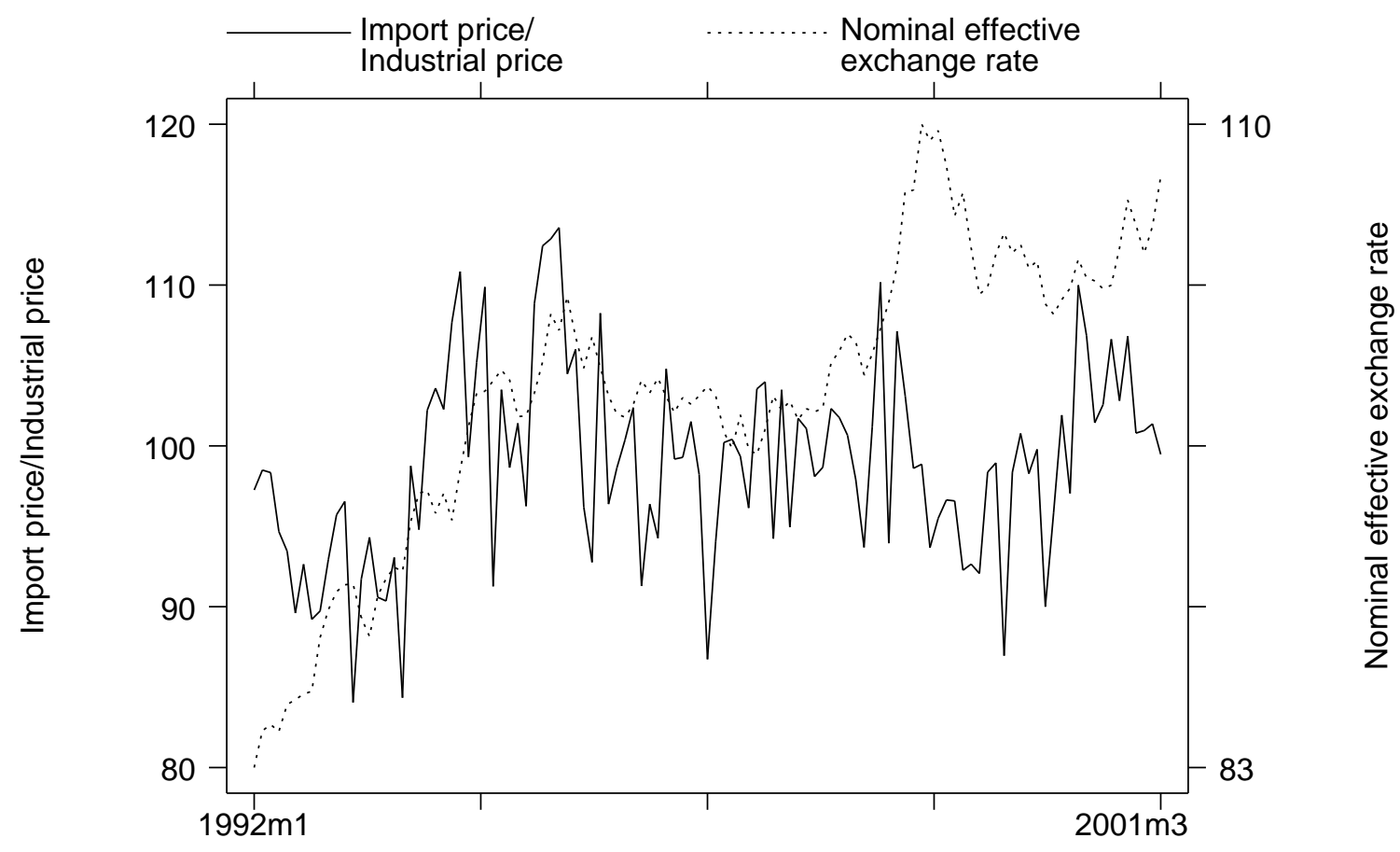

Fish 
Figure 12

Import-industrial price ratio and nominal effective exchange rate movements

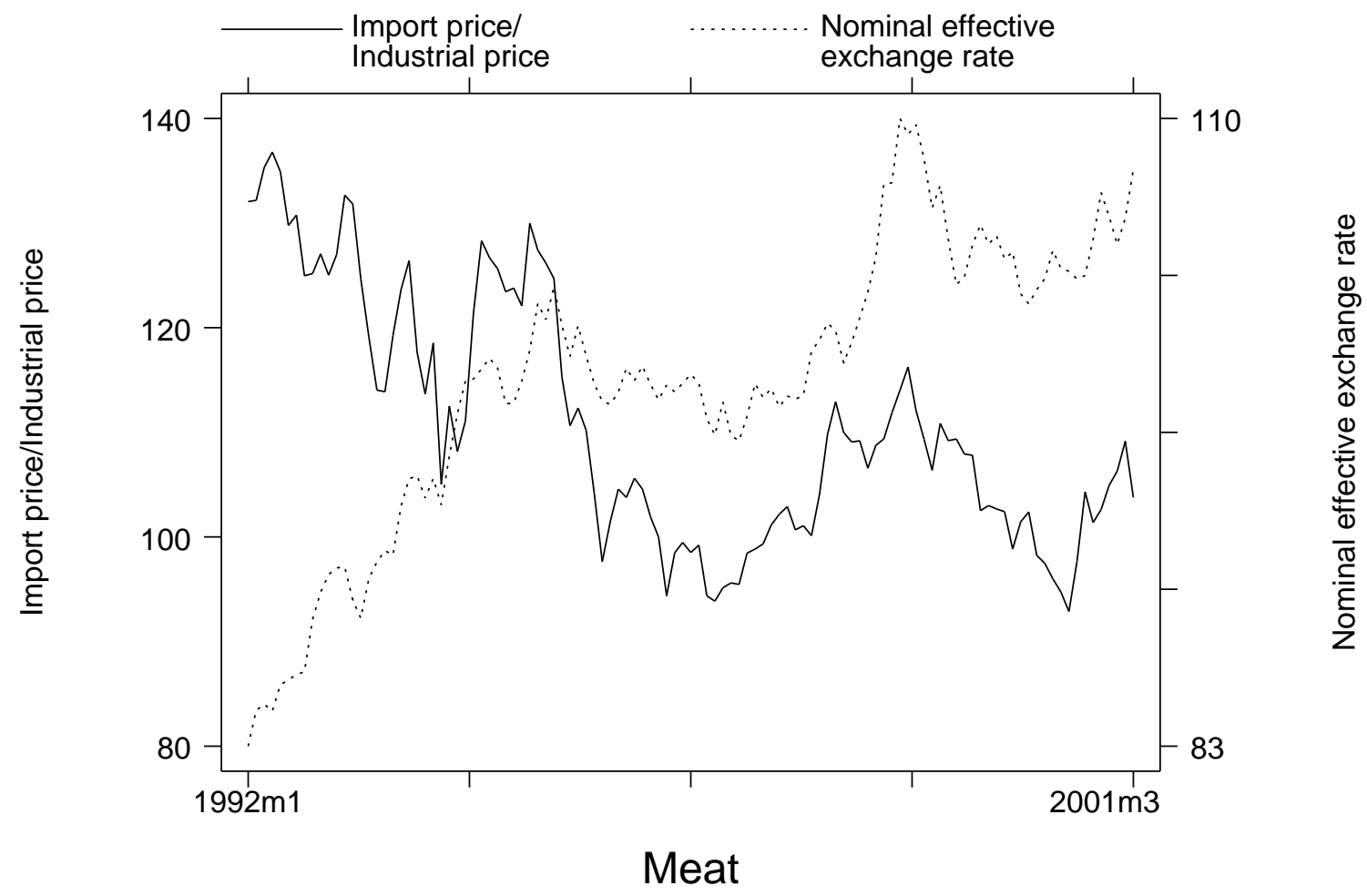


Figure 13

Import-industrial price ratio and nominal effective exchange rate movements

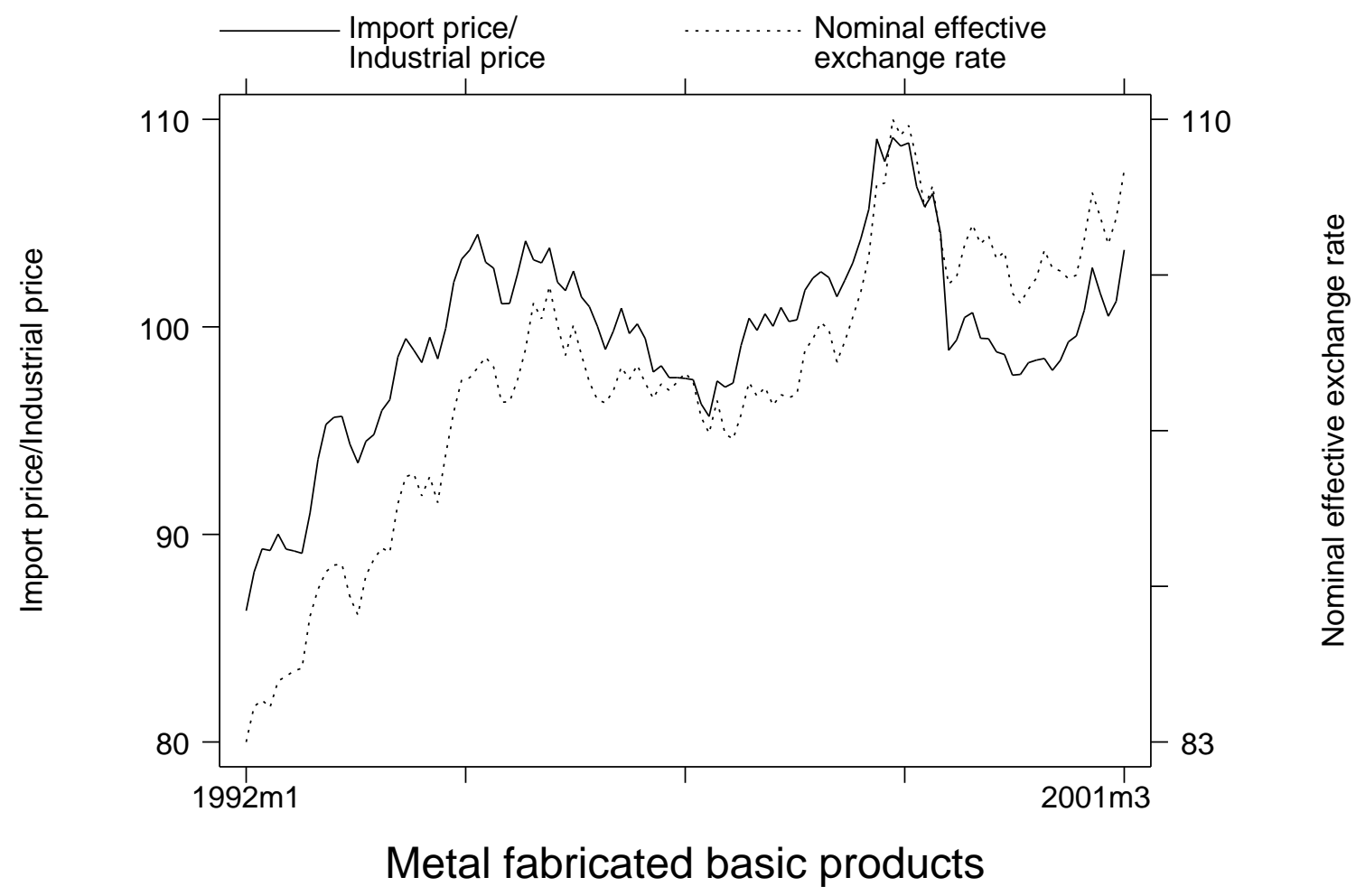


Figure 14

Import-industrial price ratio and nominal effective exchange rate movements

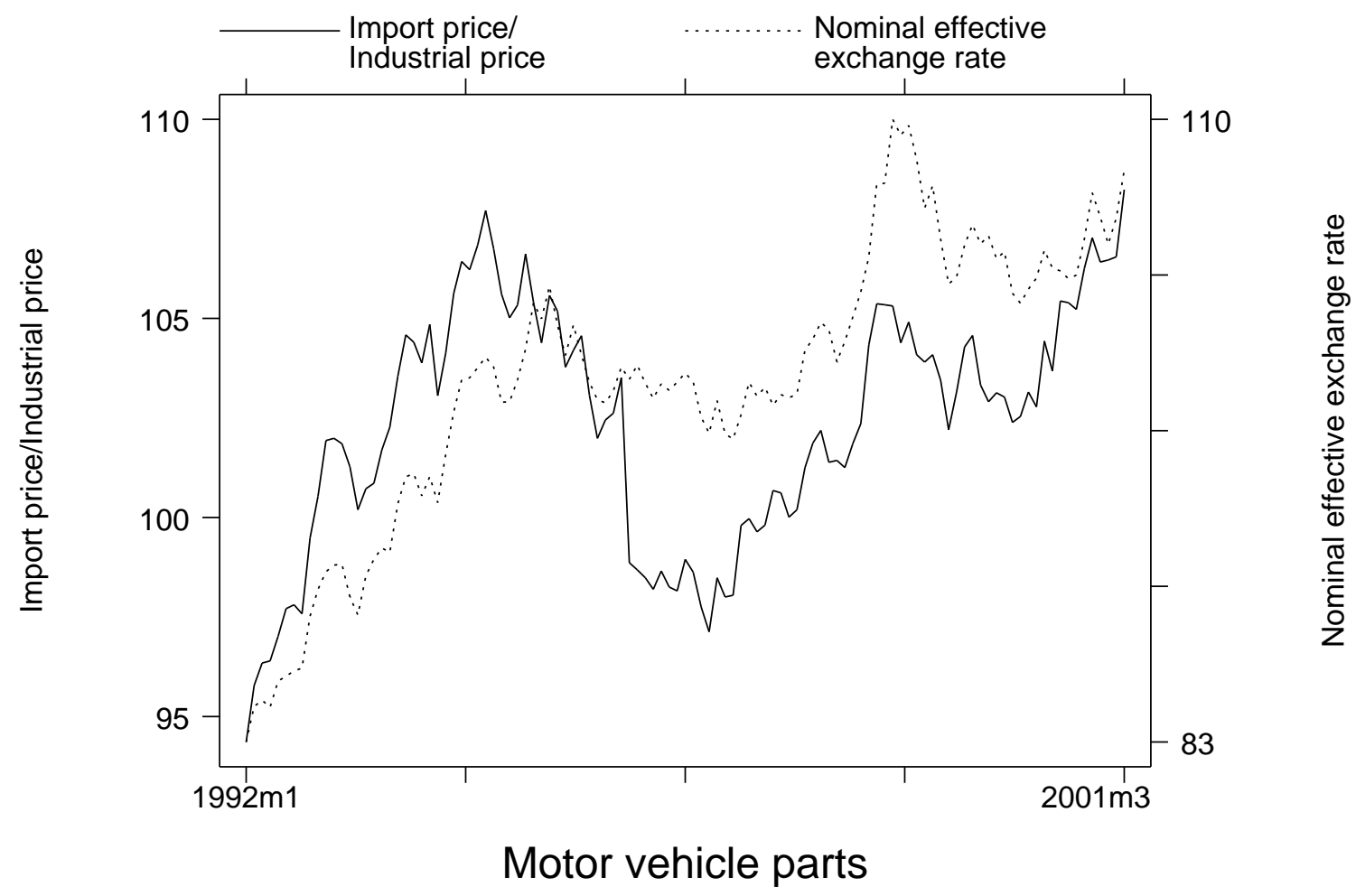


Figure 15

Import-industrial price ratio and nominal effective exchange rate movements

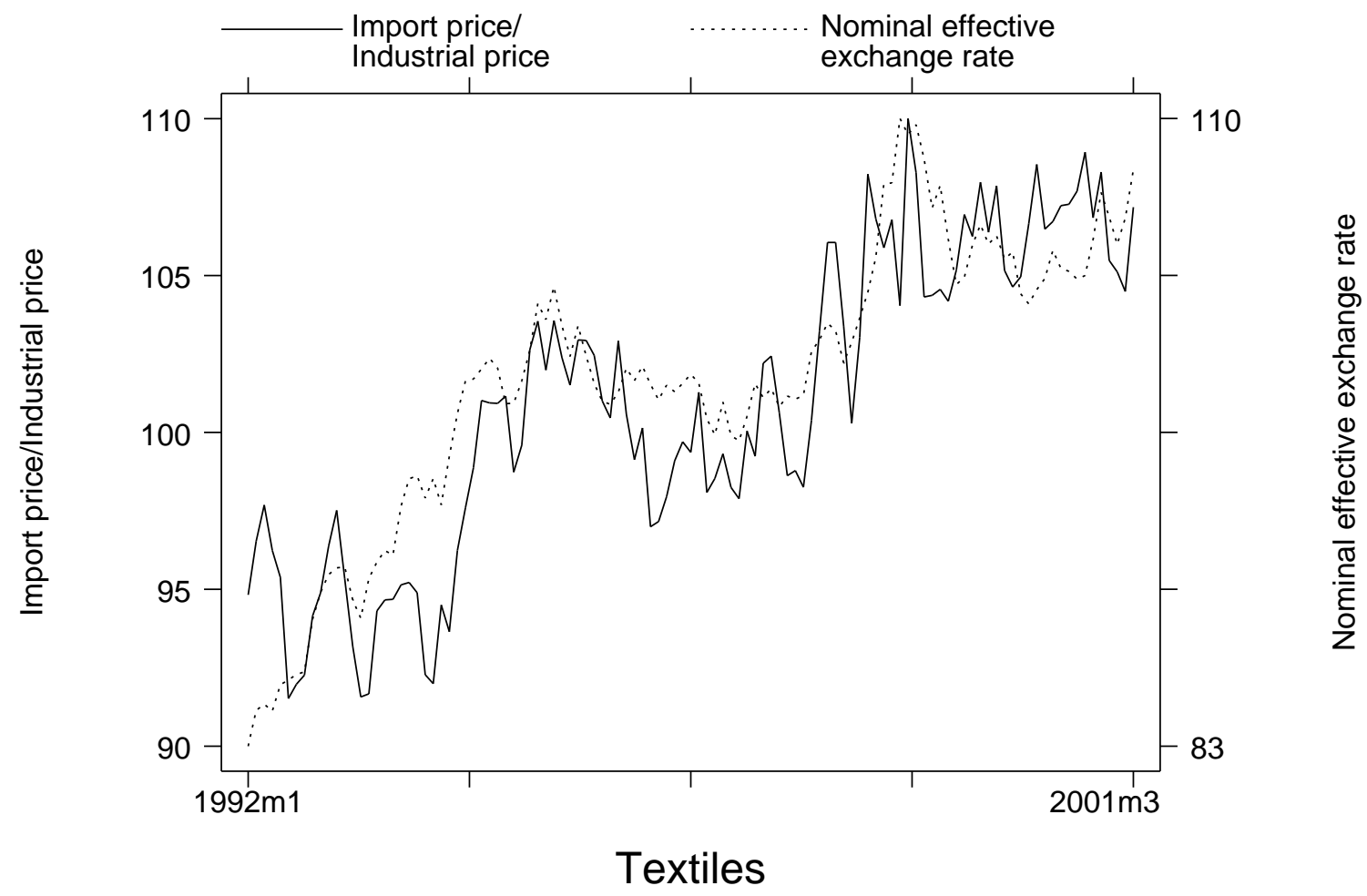


Figure 16

Import-industrial price ratio and nominal effective exchange rate movements

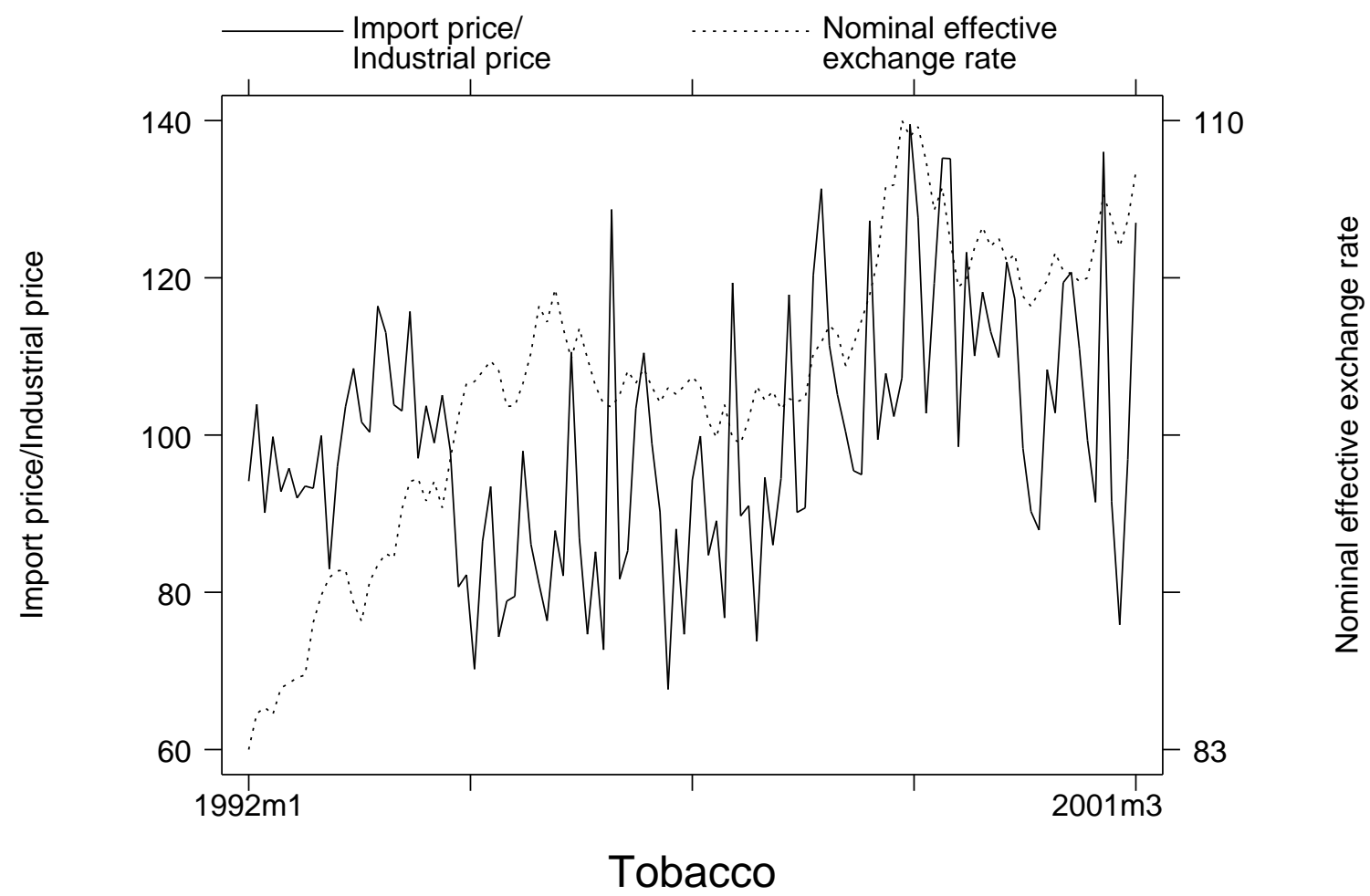

